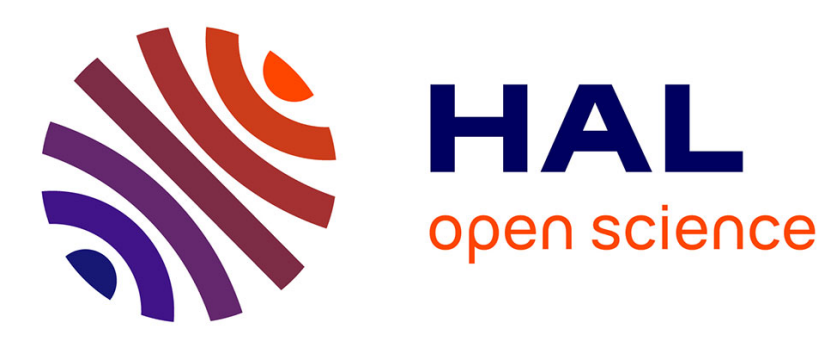

\title{
THE NETWORKS OF QUARRELS: THE STRANGE CASE OF PETER ANTHONY MOTTEUX
}

\author{
Alexis Tadié
}

\section{To cite this version:}

Alexis Tadié. THE NETWORKS OF QUARRELS: THE STRANGE CASE OF PETER ANTHONY MOTTEUX. Etudes Anglaises, 2013. hal-02006430

\section{HAL Id: hal-02006430 \\ https://hal.sorbonne-universite.fr/hal-02006430}

Submitted on 4 Feb 2019

HAL is a multi-disciplinary open access archive for the deposit and dissemination of scientific research documents, whether they are published or not. The documents may come from teaching and research institutions in France or abroad, or from public or private research centers.
L'archive ouverte pluridisciplinaire HAL, est destinée au dépôt et à la diffusion de documents scientifiques de niveau recherche, publiés ou non, émanant des établissements d'enseignement et de recherche français ou étrangers, des laboratoires publics ou privés. 


\section{THE NETWORKS OF QUARRELS: THE STRANGE CASE OF PETER ANTHONY}

MOTTEUX

Alexis Tadié

The only way when friends quarrel is to see it out fairly in a friendly

manner, as a man may call it, either with a fist, or sword, or pistol, according as they like, and then let it be all over; for my own part, $d-n$ me if ever I love my friend better than when I am fighting with him. To bear malice is more like a Frenchman than an Englishman.

(Fielding : 439)

Although ancients and moderns had quarrelled for a while in France and elsewhere on the continent, it was really with William Temple's essay (1690), which defended the superiority of the ancients over the moderns, that the controversy took off in England. William Wotton's reply of 1694 ignited the debate, and for another fifteen years the debate initiated by Temple exercised a number of writers, culminating in the publication of the fifth edition of Jonathan Swift's A Tale of a Tub (1710), which incorporated some of Wotton's "Observations upon the Tale of a Tub". Pope's translation of the Iliad provided another battle-ground, while the rhetoric of the opposition between ancients and moderns was used throughout the century by writers in order to position themselves or to claim allegiances. The purpose of this paper is not to revisit the battle of the books, which some critics have seen as a fight for the protagonists' intellectual lives (Weinbrot), while others have dismissed it as "unserious, trivial, and disingenuous" (Haugen 277, n45), but rather to concentrate on a character who was also, to a lesser degree, involved in the promotion of the querelle in England. He is praised by Lady Montagu in a couple of her eclogues, for achievements which are not exactly literary:

There was a time (oh! that I could forget!)

When opera-tickets pour'd before my feet;

And at the Ring, where brightest beauties shine,

The earliest cherries of the spring were mine.

Witness, O Lilly; and thou, Motteux, tell, 
How much japan these eyes have made ye sell. ("Saturday.-The SmallPox." Montagu 446)

This character was a dealer in Chinese and Indian artifacts, kept one of these "India houses", and described himself in a letter to the Spectator: "I cannot, I think, give you a better Idea of my being a downright Man of Traffick, than by acknowledging I oftener read the Advertisements, than the Matter of even your Paper" (Spectator: vol. 3, 26). He died in obscure circumstances, accidentally strangled by prostitutes. His epitaph, written in French, reads:

\author{
Cy gît qui par pure impuissance \\ Faisant un trop puissant effort, \\ Mourut le jour de sa naissance \\ En serrant son Col par trop fort. (Missy 18)
}

Why is it that such a character could be seen as important for our understanding of the controversy between ancients and moderns, or indeed for an analysis of quarrels more generally?

\title{
1. Motteux and theatre
}

Peter Anthony Motteux, who was born Pierre Antoine Le Motteux in Rouen in 1663, was a Huguenot. He is not only remembered for his Indian transactions but also for his translations - of Don Quixote and Rabelais in particular (he completed Urquhart's translation). He would of course have liked to view both activities on the same level. In the same letter to the Spectator, he wrote, no doubt with a hint of irony: "the foreign Goods I sell seem no less acceptable than the foreign Books I translated, Rabelais and Don Quixote". In 1685, he sought refuge in England, after which he learnt English. He was made an English citizen on 5 March 1686 and was among the petitioners for permission to establish a French protestant church in London. He proved himself at ease both in French and in English, lending a political overtone to the familiar comparison between 
the two languages. Indeed, in a scathing attack against Boileau - "Ode de Mr. Boileau Despreaux sur la prise de Namur : avec une Parodie de la Mesme Ode par le Sieur P. Motteux" — he wrote:

Je vais, plus heureux que vous,

Quittans le Francois sterile

Pour l'Anglois hardi, fertile,

Rival du Grec, du Latin,

Chanter la France vaincue,

En une langue inconnue

Au docte Auteur du Lutrin. (Motteux n.d.: 15)

Motteux's opposition to Boileau was of course both literary and political. The Protestant, who had sought refuge in England, disapproved of the celebration of the siege of Namur and more generally condemned the panegyrist of Louis XIV.

Motteux was a playwright of some reputation in London at the turn of the century, publishing a number of plays, as well as being active as a librettist. He was influential in the transformation of public taste, promoting the presence of music to accompany spoken drama and helping to move the stage towards speific genres in which music, dance and spectacle became gradually more important than the play itself (Hook). He collaborated in particular with John Eccles, Henry Purcell's successor as Master of his Majesty's Music. The men followed the trend for the rewriting, with added music, of a number of Fletcher's plays, such as Valentinian (1694), The Island Princess (1699), or The Mad Lover (1701). Eccles wrote the music for some of Motteux's own plays such as The Loves of Mars and Venus (1696). They collaborated further over a number of masques for which Motteux penned the texts, such as Acis and Galatea (1701). Motteux's importance in this respect lies in his moving the form of the classical masque towards the emerging genre of the English opera. His role as translator of the libretto for the first opera in the Italian style, Arsinoe, Queen of Cyprus (1705), with music by Thomas Clayton, confirmed Motteux's position as a promoter of the arts, and as an intermediary between different cultural worlds. 
Motteux was a prolific playwright whose plays commanded a certain reputation and led him to take part in the most important dispute around the theatre, at the turn of the century. The preface to his play Beauty in Distress, published in 1698, defended the stage against the accusations of unlawfulness levelled at the theatre by Jeremy Collier. Collier's A Short View of the Immorality and Profaneness of the English Stage, together with the Sense of Antiquity upon this Argument had also appeared in 1698. Alongside more famous playwrights and critics who replied to Collier, such as William Congreve, John Vanbrugh, Thomas D'Urfey, and John Dennis, Motteux published his own response. The first part of the preface wonders at the success of his tragedy in the light of the fact that it "has no Singing, no Dancing, no mixture of Comedy, no Mirth, no change of Scene, no rich Dresses, no Show, no Rants, no Similies, no Battle, no Killing on the Stage, no Ghost, no Prodigy; and, what's yet more, no Smut, no Profaneness, nor Immorality" (Motteux 1698: vii). But its immediate point was to introduce "A Letter from a Divine of the Church of England, to the Author of the Tragedy call'd Beauty in Distress, Concerning the Lawfulness and Unlawfulness of Plays". This part of the preface presents his views on the propriety of the theatre and emphasises "the Diversion and Pleasure" as well as "the correction and information of Mankind" (Motteux 1698: ix) which the genre provides. If there are issues of morality, they are not to be found in the genre itself, but in the abuses of the stage. And therefore the "Divine" recommends that Motteux "may be a means of reforming the Abuses of the Stage, and of shewing the World that a Poet may be a man of Sense and Parts, without renouncing his Virtue" (Motteux 1698: $\mathrm{x})$.

The second part of the preface is a translation and adaptation of Francesco Caffaro's “Lettre d'un Theologien illustre par sa qualité \& par son merite, consulté par l'Auteur, pour sçavoir si la Comedie peut estre permise, ou doit estre absolument deffendue", which had been published in 1694 as a preface to the playwright Edme Boursault's CEuvres. The tone of Caffaro's letter is consonant with Motteux's introduction. Caffaro defended a compromise between the Church and the players, and argued in favour of comedy, quoting in 
particular Aquinas as an authority supporting his views - according to him, the excesses of comedy were to be blamed rather than the genre itself. The publication sparked off a quarrel in France, Caffaro was forced to retract, and Bossuet condemned him in his Maximes et Réflexions sur la comédie of the same year. Bossuet's publication, perhaps the most famous of a number of responses to Caffaro's letter, was aimed at providing the final word on the matter and at terminating the quarrel: "songez seulement si vous oserez soûtenir à la face du ciel, des pieces où la vertu \& la pieté sont toûjours ridicules, la corruption toûjours excusée \& toûjours plaisante; \& la pudeur toûjours offensée, ou toûjours en crainte d'estre violée par les derniers attentats, je veux dire par les expressions les plus impudentes, à qui l'on ne donne que les enveloppes les plus minces" (Bossuet 6).

Motteux's preface to Beauty in Distress is concluded with a poem by Dryden to "My Friend, the Author":

'Tis hard, my Friend, to write in such an Age,

As damns not only Poets, but the Stage.

That sacred Art, by Heav'n it self infus'd,

Which Moses, David, Salomon have us'd,

Is now to be no more. (Motteux 1698: 27)

- something which refers, of course, both to Motteux and to Dryden himself. Motteux had developed a friendship with Dryden, which testifies to his presence in literary circles. While Motteux introduced in English, and in the English quarrel around theatres, arguments developed in France over the morality of theatre, his translation of Caffaro's Letter led to the publication in English of Bossuet's reply under the title Maxims and Reflections upon Plays, the subtitle of the book being: "In answer to a Discourse, Of the Lawfullness and Unlawfullness of Plays. Printed before a late Play Entitled, Beauty in Distress". It was published in 1699, with a preface "by another hand", perhaps by Collier himself. So that Motteux's intervention in the quarrel around the morality of the stage in England imported directly some of the arguments that had sparked off a similar 
controversy in France. Motteux's preface also occasioned a direct attack from George Ridpath, the presbyterian author of The Stage Condemn'd (1698); he attacked Motteux who "has Sacrificed the Authority of the Protestant Church of France, to the Pleasure and Profit he reaps from the Theatre and Drama" (Ridpath 74).

With this preface, Motteux had taken a stance in a quarrel which had deep political implications, since Collier's objections to the theatre tied in with his opposition, as a non-juror, to the 1688 revolution: "the theatre seemed to represent exactly those notions of atheism, disorder and contempt for authority which had triumphed in 1688" (Hopes 166). The quarrel about the theatre was not only concerned with the morality of the genre, but with wider issues concerned with religious conflicts as much as with religious doctrine. The defenders of the theatre, and in particular the author of The Stage Acquitted, - a reply to Ridpath's pamphlet - argued in favour of reason and tolerance as opposed to authority, and were in tune with the growing emphasis on politeness and civility (Freeman 148). Motteux's direct involvement in the quarrel produced several results. He introduced in an English context arguments voiced in France, thereby translating the dispute, in keeping with his role as an intermediary between the two countries. He took an active part in the general argument around theatre, both in terms of the evolution of genres and tastes, and in the contribution that theatre could make to the definition of a public, social space. His involvement in the quarrel around theatre was consonant with his political and aesthetic choices.

\section{Motteux between the Ancients and the Moderns}

Whereas the very idea of a polite conversation, which is generally regarded as characterising the emerging public sphere, conjures up an irenic rather than a conflictual dimension, the quarrel around the morality of the theatre was one of the ways in which that ideal became established. Alongside his activity as playwright, librettist, and polemicist, Motteux contributed to the fashioning of 
the new sociability through the first periodical in English which he founded in 1692. Originally boasting sixty-four pages, the Gentleman's Journal, or, The Monthly Miscellany. By Way of Letter to a Gentleman in the Country. Consisting of News, History, Philosophy, Poetry, Musick, Translations, \&c. was a monthly publication which started in January 1692 while its last issue was dated from October 1694. Although it claimed to distance itself from the Mercure Galant, it was explicitly modelled on the French publication, which reinforced Motteux's role as an intermediary between the French and English worlds of letters:

The French have had a Letter of this nature, called, Mercure Gallant, every Month for many Years. Its Author, like most of the Panegyrists of the French Court, hath been accused of Profuseness in his Praises to an unsufferable Excess. I will strive to eschew his Fault, and avoiding trifling matters as much as possible, will altogether decline the Flatteries and Daubing that have prejudiced against him, all that love Candor and Impartiality as much as I do. (Gentleman's Journal 1)

The first issue presented its readers with a variety of essays, ranging from accounts of opera or theatre, to disquisitions on natural philosophy ('An Account of the Nature of Driness and Moistness'), fables, translations of verse by Horace, songs, enigmas, among others. The opening letter of the first issue indicated clearly that the aim of the publication was to divert and benefit the public, while it celebrated the achievements of the English armies. Given the central position of London, he saw his periodical as a privileged position from which to convey news: "I grant that from London, the Heart of the Nation, all things circulating to the other parts, such News of new Things as are sent me, may be conveyed everywhere, being inserted in my Letter". This required of course that news should be sent to the journal for the enterprise to succeed: "'tis to be hop'd I shall have enough sent me to make the Undertaking easie to me". Motteux was not only able to relay opinions but also to take an active part in the general conversation around the arts. Thus, he repeatedly advocated in the pages of the Gentleman's Journal a taste for Italian opera, urging the English to embrace the form (Hook 106-8). 
It has been argued that the Gentleman's Journal enacted not so much a transformation in tastes as an integration of older forms of literary life into a new format: "The contents of the Gentleman's Journal do not... signal a change in the literary tastes of the Restoration reader so much as the integration of coterie literary circles and their practices in a commercial venture" (Ezell 326). The Journal elicited a form of participation with the audience that would have been familiar to literary circles of the Restoration and some of the submissions appear to originate from circles in which manuscript circulation would have been the norm. In contributing to the transition from amateur literary circles to a gradual professionalisation of the literary world, the Gentleman's Journal played an important part in the fashioning of a public sphere. It also echoed wider debates and offered readers an insight into arguments that may not have necessarily been available, or of direct interest, to them.

In the second and third issues of the Journal (February and March 1692), Motteux published a summary of the "querelle des anciens et des modernes", which is arguably one of the first accounts to be given in England of the general debate around the possible superiority of ancients or moderns; entitled "A Discourse concerning the Ancients and the Moderns", it is an element in the translation of the querelle to England. The Journal's contribution appeared between Temple's essay, published in 1690, and Wotton's reply of 1694. It was clearly addressed to a more general reader than either of the two main contenders in the quarrel, and can be seen as an important element, not only in the diffusion of the querelle from France to England, but also in the availability of its idiom. It may prefigure in some ways the tone in which the debate subsequently took place in the periodical press.

The Journal introduces the querelle both in its French context, that of Perrault's Le Siècle de Louis le Grand, and in its English context. The French context is summarised as follows: 
All the Flatterers and several Authors sided with our Academist; but a good number of learned Men, who had bestowed a good part of their life on the Ancients, drew their Pens in their defence. This difference made sport to the Impartial, some of whom observing that both Parties were partly in the right, and in the wrong, stept between, and writ to reconcile them, and descending to Particulars, to compare the Inventions and Writings of the Ancients, and the Moderns, shewed, that tho' the first were before us in several things, yet in many others the last did not yield to, but even surpassed them. Almost all the Judicious joined with this third Party, and this soon put an end to this Contest. However, most People kept to their old Opinion, as it happens in all other Disputes. (Motteux, February 1692: 18)

The English context mentions Temple's writings on the subject as well as a couple of essays by Thomas Pope Blount, published in 1691: "Of the Ancients: And the Respect that is due unto them: That we should not too much enslave our selves to their Opinions" and "Whether the Men of this present Age are any way inferiour to those of former Ages, either in respect of Vertue, Learning, or long Life". Blount's essays fell clearly on the side of the moderns, although they were not aimed directly at Temple - they certainly suggest that the case for the moderns was being made at the same time as the case for the ancients. Motteux's contribution hoped to resolve the argument.

The first part of the discourse opens up with a concise summary of many years of disputes: "The whole Question of the Pre-eminence between the Ancients and the Moderns being once rightly understood, comes to this: Whether Trees were formerly higher than they are now? If so, Homer, Plato, Demosthenes, cannot be equalled in these latter Ages: But if our Trees are as tall as those of old, we may equal them" (Motteux, February 1692: 18). This conceit ushers in a reflection on the fact that admiration for the ancients is incompatible with the findings of natural philosophy, which teaches us that it is impossible to consider that "Nature hath exhausted her self to produce those great Originals" (Motteux, February 1692: 19). What matters is simply that we are the product of 
circumstance. Motteux explains that factors such as time or government play a key role in shaping men, but that historical conditions are not always favourable to arts or learning. In particular, invasions, governments opposed to learning, prejudices and wars cause ignorance in a society. More specifically, Motteux only concedes that the achievements of the Ancients are due to the fact that "they were before us". In passing, he rejects firmly one of the common implications of the arguments of the ancients, the idea that modern times are characterised by steady degeneration since ancient times: "There is no likelihood that Men should degenerate; and the sound Ideas of all the Ingenious that shall succeed one another will still add themselves to the former" (Motteux, March 1692: 21). Against this idea, Motteux and the moderns argued in favour of the constant progress of knowledge.

Far from proving the superiority of the ancients, their position as ancients brings about two consequences. The first is that they have erred and that the moderns may correct their false ideas. More generally, the moderns may be enlightened by the findings of the ancients and therefore will surpass them. In rhetoric, Motteux is prepared to concede that the ancients have reached a measure of perfection, but he argues that in poetry, in natural philosophy, and in particular in reasoning, a discipline vastly improved by Descartes, the moderns have bettered the ancients. For Motteux, the ancients were particularly deficient in this matter: "With them weak Conveniencies, little Similitudes, Witticisms not over solid, wide and confused Discourses and Excursions, often pass for Proofs" (Motteux, March 1692: 21). The second consequence is that this insistence on the flow of time implies necessarily that "we shall one day be Ancients too". Thus, he compares the Romans with the Greeks, showing that, except in the matter of tragedy, the Romans were superior to the Greeks, and hence were "moderns with respect to the Greeks" (Motteux, February 1692: 19). Motteux calls for a treatment of the ancients that does not rely on respect for their names, but that considers them as moderns. Indeed, praise for the ancients is to be avoided: "Nothing hinders more the progress of Learning, nor so much confines Minds as an excessive admiration of the Ancients" (Motteux, February 1692: 23). He ends his discourse with a firm rejection of the philosophy of Aristotle, which has 
hindered the progress of knowledge through excessive devotion to the authority of an ancient. He also hopes that Descartes will not prompt similar blind servitude in the future.

Motteux adopted a tone aimed at appealing to the general reader and perhaps at preserving the appearances of an impartial tone. The ancients were, of course, drawn to false ideas, which the author does not hold against them, since the progress of knowledge takes time and energy. He concluded logically that the moderns were necessarily superior in this respect - to have only equalled the ancients would have been the proof of a nature inferior to theirs. The whole argument shows a familiarity with a number of points which were being made in the French querelle, using rhetoric not unlike that which was promoted by Bacon and the Baconians (and which may well have come back to the Gentleman's Journal by way of France), arguing forcibly for the superiority of the moderns, at the same time as allowing the ancients some sense of achievement. Unlike other episodes in the battle of the books, which may have been more violently argued, exemplified most graphically by Jonathan Swift's Battel of the Books, Motteux was keen to steer clear of direct confrontation. The essay does not name any of the defenders of the ancients (nor indeed of the moderns) and the only direct oppositions involve classical writers ("Cicero seems to me before Demosthenes, Virgil before Theocritus and Homer, Horace before Pindar, Livy before all the Greek Historians" Motteux, February 1692: 19) or Aristotle and Descartes. Motteux wished, rather, to present to the Journal's readers a line of argument that was clearly aimed at gentlemen and gentlewomen, but which was equally clearly on the side of the moderns. Thus, the querelle reached England, in ways that not only highlight the importance of the great texts but also the essential role played by translators and writers of essays. The controversy was performed at several levels, involving the main protagonists (such as Temple or Wotton) as well as lesser writers.

3. The Gentleman's Journal, the periodical press and the networks of quarrels 
Whereas the essays published by Temple and Wotton presented long and sometimes fierce arguments in favour of one side or the other, the periodical press took sides in a different tone. The Gentleman's Journal was of the view that the moderns are superior to the ancients. But the Guardian, for instance, in an essay anonymously penned by Pope, prefered to attack modern critics, which it called "Pretenders to Criticism" (Guardian 77). This was a theme to which Addison returned in The Spectator: "it is our Misfortune, that some who set up for professed Criticks among us are so stupid, that they do not know how to put ten Words together with Elegance or common Propriety, and withall so illiterated, that they have no Taste of the learned Languages, and therefore criticise upon old Authors only at second-hand" (Spectator: vol. 5, 26). Addison also thought that the ancients were superior in most of the arts and exercised more good sense: "We may observe, that in the First Ages of the World, when the great Souls and Master-pieces of Human Nature were produced, Men shined by a noble Simplicity of Behaviour, and were Strangers to those little Embellishments which are so fashionable in our present Conversation. And it is very remarkable, that notwithstanding we fall short at present of the Ancients in Poetry, Painting, Oratory, History, Architecture, and all the noble Arts and Sciences which depend more upon Genius than Experience" (Spectator: vol. 3, 467). In his Discourse on Ancient and Modern Learning, he drew a (conventional) list of the advantages of the ancients compared to those of the moderns. So that, while it was contributing to the fashioning of a public sphere in which manners and gentlemanly politeness reigned supreme, like the Gentleman's Journal, the Spectator also took sides in this quarrel, and found ways to echo some of the arguments that had been levelled at the moderns.

Addison returned to the question of modern philology which he deemed to be of no use to man, and to impede the progress of reading and the understanding of ancient texts: "I have been very often disappointed of late Years, when upon examining the new Edition of a Classick Author, I have found above half the Volume taken up with Various Readings. When I have expected to meet with a Learned Note upon a doubtful Passage in a Latin Poet, I have only 
been informed, that such or such Ancient Manuscripts for an et write an $a c$, or of some other notable Discovery of the like Importance." (Spectator: vol. 4, 159-60). In The Tatler, both Steele and Addison had treated the pedants with equal contempt: "Of this kind very often are Editors, Commentators, Interpreters, Scholiasts, and Criticks; and in short, all Men of deep Learning without common Sense" (Tatler: vol. 2, 386). This issue, which was central to the Scriblerians' satire, had also increased the disagreement between ancients and moderns in England, and is reminiscent of the quarrel around the authenticity of the letters of Phalaris.

Temple's essay had insisted on the excellence and authenticity of the letters of Phalaris, a Sicilian tyrant of the $6^{\text {th }}$ century BC, because this was in keeping with his belief in the superiority of the ancients. Unfortunately, the letters were late forgeries. Bentley's famous reply, A Dissertation upon the Epistles of Phalaris, Themistocles, Socrates, Euripides, and others; and the Fables of Asop, was printed with the second edition of Wotton's Reflections in 1697, showing beyond doubt that the letters were forgeries. But Bentley's purpose was not to take part in a controversy over ancient and modern learning: "I write without any view or regard to your Controversie; which I do not make my own, nor presume to interpose in it. 'Tis a Subject so nice and delicate, and of such a mixed and diffused nature, that I am content to make the best Use I can of both Ancients and Moderns, without venturing with you, upon the hazard of a wrong Comparison, or the envy of a true one" (Bentley 6-7). Rather, his approach, in exposing the forgery, was that of the scholar who offers proof that the style of the letters is from a late period. This was based on his knowledge of the Greek language and on a precise, detailed comparison between different writers.

Bentley was attacked by Charles Boyle in 1698 (the text was in fact penned by a group of people, including Francis Atterbury) but he responded with an enlarged edition of his Dissertation, which relied essentially on linguistic and literary analysis and to all intents and purposes resolved the question. It is very much a scholarly text, with extensive footnotes and technical arguments. But the opposition between Atterbury and Bentley also tied in with a controversy in the 
Church of England between the high-church party, to which Atterbury belonged, and the latitudinarian party, with which Bentley was aligned: "The Phalaris controversy, or any rate its gross efflorescence, was thus in part a proxy war for a contemporary political issue of very serious implications. This fact must have encouraged general interest in the quarrel; it would also have created a readymade audience sympathetic to the case against Bentley" (Haugen 123). Although Bentley was right, he probably lost the argument in public opinion (Haugen 123) rather than on scholarship grounds - Boyle suggested ironically that Bentley's dissertation was not genuine and that “Dr Bentley's Way and Manner, and for the most part in his very Words too, argue against their being truly His to whom they are ascrib'd" (Boyle 184). These publications transformed what could have been a circumscribed quarrel into a public and complex debate around issues of learning, of scholarship, and of argumentation. The echoes of this debate are still to be heard in satirical texts such as Swift's Tale of a Tub, as well as in essays in the periodical press. The periodical press did not reproduce the arguments, nor was it aimed at discussing in depth issues of authorship or scholarship. On the other hand, it displayed an awareness of these debates, and was prepared, on occasion, to express its preference and to make it known to its readers. Addison's doubts about "pedantry" were fostered both by his valuation of the ancients, and by his desire to adopt a position which valued "common sense".

Whereas Motteux did take part in the dispute around the theatre, publishing texts and documents that showed a direct involvement in the controversy, he took an obvious stance when he presented the ancients and moderns, but without singling out his enemies. Likewise, Addison made his feelings clear as to how he viewed modern critics and modern philology, but without engaging directly in a controversy. Thus, if there was a distinct move towards the fashioning of a public sphere based on polite conversation and manners, such as was promoted by The Tatler or The Spectator, and by the periodical press in general, we may want to consider that such an evolution implied, at some level, debates, disputes, controversies. Quarrels and disputes circulated, and were redefined. At one level, quarrels were circumscribed arguments that dealt with a concrete, specific issue. The immorality of the 
theatre, the superiority of the ancients or the moderns, or the authenticity of spurious Greek texts all started with a specific publication, whose contents were then attacked in other publications or pamphlets. It might also be argued that quarrels did not so much begin with the publication of an original text, such as Temple's "Upon Ancient and Modern Learning" or Collier's A Short View of the Immorality and Profaneness of the English Stage, but with the first reply to such texts - quarrels begin because someone chooses to respond to a perceived offence. These arguments were then articulated in a number of publications, which may have involved the reiteration of older debates, the translation of controversies from another language, as well as new editions of previously published works - the two editions of Bentley's Dissertation, the first three editions of Wotton's Reflections, the fifth edition of Swift's Tale of a Tub are examples of the ways in which quarrels developed through publishing practice.

Quarrels involve a public dimension, a consequence of the modes in which they are carried out, through the publication of essays, dissertations, treatises or pamphlets, but also because they require the sanction of the public as the ultimate judge. As Haugen has shown, this is something that Bentley struggled with, and which was crucial: "How could Bentley convince his readers that the judgments of his genius and taste were correct?" (Haugen 123). In this sense, quarrels do not simply oppose individuals but involve groups of various natures, and possibly a wider public. This is where the periodical press may provide an echo to more circumscribed arguments. Quarrels touch on wider, more complex and sometimes more profound issues than the apparent arguments which are voiced. The immorality of the theatre, like the quarrel over the letters of Phalaris, conveyed political and religious overtones also relevant to a structuring of the disputes. Likewise, the ancients and moderns controversy was caught in complex networks that implied issues to do with belles lettres, as well as the political positioning of some of the protagonists, the nature of the medium in which the argument was conveyed, and perhaps also other disputes that were not obviously connected. Indeed, quarrels also intersect and connect. A man such as Motteux, who was involved in making available the idiom of the French querelle in England, was also involved in the argument around the theatre. In both cases, 
he was at the centre of a network that implied, as well, the translation of French disputes applied to English debates.

Having fled France, Motteux still used his knowledge of his native country to make an impression in the world of English letters, through the translations of writers such as Rabelais as well as pamphlets and controversies. The fact that he was involved in two major disputes of the age might suggest a quarrelsome tendency. But it is important finally to reflect on the stance he took in both disputes, one which, although distinctly modern and on the side of the defence of theatre, as well as of the moderns in general, made allowances for the other side, and wished to strike a sensible posture. This sensible posture will of course come to infiltrate the periodical press in the eighteenth century. So that, in spite of the fact that the battle of the books may have been felt by some of the protagonists as a moment of great threat, it is important to consider other, perhaps more obscure, protagonists. In the case of Motteux, we may want to remember his position as a Huguenot émigré. He would side with the defenders of the Glorious Revolution and seek, through his allegiance to the English language and to the dominant literary circles, political as well as artistic recognition. His interest in texts and disputations came with a wish to deflect, to an extent, the more violent arguments. His friendship with Dryden seems to support this perception of a character who, although he performed, and died from, rather extreme deeds, sought to keep a form of dialogue between opponents, and perhaps, malgré lui, between France and England.

\section{Alexis Tadié}

Université de Paris-Sorbonne. Institut Universitaire de France.

Versions of this paper were presented at the 2012 ASECS conference, in the "Revisiting the Quarrel of the Ancients and Moderns" panel chaired by Professor Timothy Irwin, and at the 'Battle of the Books' and the European Republic of Letters' conference convened by Paddy Bullard, at the University of Canterbury. This paper follows my “Peut-on traduire les querelles? De la Querelle des Anciens 
et des Modernes à la Battle of the Books", numéro spécial "Le Temps des querelles", Littérature classique, 2013.

Bibliography

Bentley, Richard. A Dissertation upon the Epistles of Phalaris, Themistocles, Socrates, Euripides, and Others; and the Fables of Esop. Printed with William Wotton, Reflections on Ancient and Modern Learning. $2^{\text {nd }}$ edition. London: Peter Buck, 1697.

Bossuet, Jacques Benigne. Maximes et Réflexions sur la comédie. Paris: Jean Anisson, 1694.

Boyle, Charles. Dr Bentley's Dissertations on the Epistles of Phalaris, and the Fables of Asop, Examin'd. 2 ${ }^{\text {rd }}$ edition. London: Tho. Bennet, 1698.

Collier, Jeremy. A Short View of the Immorality, and Profaneness of the English Stage, Together with the Sense of Antiquity upon this Argument. London: S. Keble, R. Sare, and H. Hindmarsh,1698.

Cunningham, Robert. Peter Anthony Motteux, 1663-1718: a Biographical and Critical study. Oxford : Blackwell, 1933.

Ezell, Margaret J. M. "The Gentleman's Journal and the Commercialization of Restoration Coterie Literary Practices." Modern Philology 89.3 (Feb. 1992): 32340.

Fielding, Henry. The History of Tom Jones, a Foundling. [1749]. Eds. John Bender and Simon Stern. Oxford: Oxford UP, 1996.

Freeman, Lisa. Character's Theater. Genre and Identity on the Eighteenth-Century English Stage. Philadelphia: U of Pennsylvania P.

The Gentleman's Journal, or, The Monthly Miscellany. By Way of Letter to a Gentleman in the Country. Consisting of News, History, Philosophy, Poetry, Musick, Translations, \&c. London: R. Baldwin, 1692-4.

The Guardian. Ed. John Calhoun Stephens. Lexington: The U of Kentucky P, 1982. Haugen, Kristine Louise. Richard Bentley. Poetry and Enlightenment. Cambridge, Mass. and London: Harvard UP, 2011.

Hook, Lucyle. "Motteux and the Classical Masque." British Theatre and the Other Arts, 1660-1800. Ed. Shirley Strum Kenny. Washington: Folger Shakespeare Library ; London : Associated UPresses, 1984. 105-15.

Hopes, Jeffrey. "Politics and Morality in the Writings of Jeremy Collier." Literature and History, 8 (1978): 159-74.

Montagu, Mary Wortley. The Letters and Works of Lady Mary Wortley Montagu. 3rd edition, vol. 2. London: Henry Bohn, 1861.

Missy, César de. "Préface du traducteur." Remarques sur les CEuvres de Maître François Rabelais Publiées en Anglois par Mr Le Motteux. CEuvres de Maître François Rabelais. tome III, nouvelle édition. Amsterdam: Jean Frédéric Bernard, 1741.

Motteux, Peter Anthony. "A Discourse concerning the Ancients and the Moderns." The Gentleman's Journal. Part 1. February 1692.

---. "A Discourse concerning the Ancients and the Moderns." The Gentleman's Journal. Part 2. March 1692. 
---. Beauty in Distress. A Tragedy. With a Discourse of the Lawfulness \& Unlawfulness of Plays. London: Daniel Brown, 1698.

---. Ode de M. Boileau Despreaux sur la prise de Namur avec une Parodie de la Mesme Ode par le Sieur P. Motteux. London: R. Bentley, n.d.

Ridpath, George. The Stage Condemn'd, and the Encouragement Given to the Immoralities and Profaneness of the Theatre, by the English Schools, Universities and Pulpits, Censur'd King Charles I Sundays Mask and Declaration for Sports and Pastimes on the Sabbath, Largely Related and Animadverted Upon. London: Printed for John Salusbury, 1698.

The Spectator. Ed. Donald F. Bond. 3 vols. Oxford: Clarendon, 1965.

The Stage Acquitted. Being a Full Answer to Mr. Collier and the Other Enemies of the Drama, with a Vindication of King Charles the Martyr, and the Clergy of the Church of England, from the Abuses of a Scurrilous Book Called The stage Condemned. London: John Barnes, 1699.

Swift, Jonathan. A Tale of a Tub and Other Works. Ed. Marcus Walsh. Cambridge: Cambridge UP, 2010.

The Tatler. Ed. Donald F. Bond. 3 vols. Oxford: Clarendon, 1987.

Temple, William. "Upon Ancient and Modern Learning." Miscellanea. The Second Part. In Four Essays. 2nd edition. London: Ri. Simpson, 1696.

Weinbrot, Howard. "He Will Kill Me Over and Over Again': Intellectual Contexts of the Battle of the Books." Reading Swift. Papers from the Fourth Münster Symposium on Jonathan Swift. Eds. H. J. Real and H. Stöver-Leidig. Munich: Fink, 2003. 225-48.

Wotton, William. Reflections on Ancient and Modern Learning. London: Peter Buck, 1694. 